The mast is of trellis-work steel construction, supported by two porcelain insulators on a solid block of concrete about twenty feet square. The shape of the mast is that of two elongated square pyramids, set base to base, and standing on one of the points, the whole structure being guyed at the centre point where the cross-section is a maximum. The height of the mast is $932 \mathrm{ft}$., but a telescopic steel pole at the top extends this to nearly $1,022 \mathrm{ft}$. or 310 metres. This height surpasses that of the Eiffel Tower by some $40 \mathrm{ft}$. and makes the mast the highest structure in Europe. The new transmitter, which is of British design built in the contractors' factory at Budapest, is situated in a building about half a mile away from the aerial, the radio-frequency power to which will be supplied through a suitable transmission line. The station is designed to supply an unmodulated carrier-wave power of $120 \mathrm{kw}$. into the aerial, and it will take over the wave-length of 550 metres used by the present transmitter. The latter, which has a power of $18.5 \mathrm{kw}$, will be retained for use on another wave-length to supply an alternative programme of less general interest than that provided by the main transmitter. The new station has already started testing at midnight, and it is likely that RadioBudapest, which employs three women and two men announcers, will be one of Europe's best-received signals this winter.

\section{Prehistoric Society of East Anglia}

AT the London meeting of the Prehistoric Society of East Anglia held on October 25 at the Society of Antiquaries, Mr. J. B. Calkin described researches in the marine raised beaches of Sussex. The $135 \mathrm{ft}$. raised beach at Slindon Park has yielded rolled Clactonian, Chellean, early Le Vallois and early Acheulean implements, with little or unrolled late Acheulean in the top layer, which is thus dated to the Acheulean interglacial period and necessitates a sea margin at more than 100 feet above present levels. On the beach occurs a floor industry of a crude Le Vallois type covered by a layer of Combe Rock. The lower (80-90 ft. O.D.) beach is probably intermediate in age between the $135 \mathrm{ft}$. and the Brighton raised beach. Major E. R. Collins exhibited examples of an industry of Upper Palæolithic character in black chert from buried 'floors' in Nidderdale, Yorkshire. The well-worked cores and flake implements have been compared with Aurignacian types by Prof. H. Breuil, and with the Cresswell finds. Mr. L. S. V. Venables exhibited a series of remarkable 'curved points' of finely chipped flint from sites on the Sussex greensand. Mr. L. V. Grinsell described the results of a study of the forms and proportions of Bronze Age barrows of the 'bell' type, particularly those of Wessex. The survey showed that Thurnam's 'bowl', 'bell' and 'disc' types form an evolutionary series connected by intermediate forms. Excavation records support the view that the 'bell' form is intermediate in age between the 'bowl' and 'disc' types.

\section{Endowment of Industrial Research}

IN an article contributed to the Nineteenth Century for November, Mr. H. W. J. Stone reviews the present position of the research associations in Great Britain at the exhaustion of the Million Fund, while industrial conditions are still difficult. Although in the current year the vote of the Department of Scientific and Industrial Research has been increased by $£ 70,000$ to enable it to facilitate the work of these associations, the existence of most of them remains precarious. Mr. Stone uses the recent vicissitudes of the Research Association of British Rubber Manufacturers as an example of the evils attending our present haphazard methods of financing such industrial research. He urges that true economy and efficiency in industrial research require a settled programme subject to long-range review, together with a stabilised system of finance, based on levies, block grants or similar expedients for a term of years, so as to place the industrial research associations in the position of institutions existing on fixed endowments, the programmes and endowments being reviewed periodically by Parliament at intervals of not less than five or more than ten years. In place of a compulsory levy, he suggests the allocation of $£ 2,000,000$ from the new tariff revenue, estimated at $£ 24,500,000$ in the current financial year, for the endowment of industrial research. By the allocation from this new revenue of that sum for ten years to create a capital fund of 20 millions, invested to produce a steady and regular income, industrial research would at once be stabilised and at the end of ten years endowed for all time. Mr. Stone ably pleads the value of research in periods of depression, its place in national recovery and the need of ensuring that tariffs do not foster industrial sloth and inefficiency.

\section{Planning}

IN a recent number of a fortnightly broadsheet entitled Planning, issued by P.E.P. (Political and Economic Planning), 16, Queen Anne's Gate, London, S.W.1, the subject of "Community Services" is discussed. The administrative organisation of community services, it is argued, has become largely obsolete in view of the new technique elaborated in other spheres for managing large units, eliminating waste, co-ordinating effort and generally for giving better value to the consumer. The primary need is full and up-to-date information. While physical science has been classifying everything in the world, and producers have begun to appreciate the need for market research, community services are carried on largely in the dark. Possibilities of co-operation between education, health services and industry have been neglected; even simple totals of recruitment into each main industry are not directly obtainable. There is an immediate need for establishing a social research council enjoying official status, comparable to that of the Medical Research Council, with sufficient resources to investigate and co-ordinate the work hitherto undertaken by numerous official, semi-official and voluntary organisations. Such economic services as gas supply, water supply, transport and sewage, which have been developed with great ability and enterprise by many municipalities, have now reached a stage when they might 
appropriately be transferred to special regional organisations. Relieved of these purely business functions, local authorities could devote themselves with greater efficiency to their remaining duties, for which they should be given greater responsibility and autonomy than in the past.

\section{British Empire Cancer Campaign}

AT the recent quarterly meeting of the Grand Council of the British Empire Cancer Campaign, the following grants for the calendar year 1934 were made for the continuation of research into the cause and cure of cancer: Middlesex Hospital, $£ 5,400$;

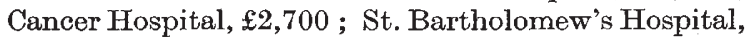
$£ 2,250$; St. Mark's Hospital, £540; Marie Curie Hospital, $£ 540$; Radon Centre at the Middlesex Hospital (through the Medical Research Council), $£ 350$; Mount Vernon Hospital, £900; Strangeways Research Laboratory, Cambridge, £350; Westminster Hospital Annexe, $£ 300$; Mr. I. Hieger (at the Cancer Hospital), $£ 550$; Dr. P. R. Peacock (Glasgow Royal Cancer Hospital), $£ 300$ and Dr. Alexander Haddow (at the University of Edinburgh), £200. Prof. E. Mellanby, who has succeeded the late Sir Walter Fletcher as secretary of the Medical Research Council, was elected a member of the Grand Council. The Grand Council resolved that attention should be invited to the fact that essays on "The Biological Effects and Mode of Action of Radiations upon Malignant and other Cells" for the 1933 Garton. prize medal should reach the offices of the Campaign not later than December 31 next.

\section{Earthquake in the Santa Elena Peninsula, Ecuador}

WE have received from Dr. George Sheppard, State geologist in the Republic of Ecuador, a brief account of the severe earthquake that occurred at 10.31 a.m. on October 2 in the Santa Elena peninsula, Ecuador. Off Salinas, the cable that runs southward was broken at a distance of 14 miles from land. At La Libertad, the sea receded immediately after the earthquake, rose to high-tide level at 11.30 a.m. (low tide having been at about 10 a.m.), fell to low water at noon, and rose again to the former mark at 2 p.m. At Ancon, the ground was seen by Dr. Sheppard to be slowly undulating, and the water in a large tank flowed over the north-east side, from which it is inferred that the origin lay towards the west and beneath the Pacific. Among the after-shocks was one at 5.36 a.m. on October 3, of only slightly less intensity than the principal earthquake. It would seem, from the above account, that the epicentre was not far from that of the Colombian earthquake of January 31, 1906, the first of the three great earthquakes of that year that occurred along the Pacific coast of America.

\section{Cultivation of Raspberries}

Tне Ministry of Agriculture and Fisheries has recently issued Advisory Leaflet No. 180 to set forth the results of modern research upon the cultivation of raspberries. The characteristics of present-day varieties are enumerated, and general directions for cultivation are given. Organic manures are deemed to be more suitable for the raspberry crop than artificials. Pruning for heavy crops of good quality demands more than mere thinning of the canes; the methods are set forth in the leaflet. Insect pests are not described, as other leaflets do this with requisite detail. Blue stripe wilt, a Verticillium disease, and mosaic, are the chief diseases. The methods of combatting the latter malady are the best that can be recommended, but the leaflet perhaps does not take sufficient notice of the fact that some of the best commercial varieties are resistant to mosaic, and therefore menaces to more susceptible varieties in the neighbourhood.

\section{Science in Poetry}

Following upon an article in Nature of August 26 entitled "Nature and Science in Poetry", Mr. E. Heron-Allen contributed to our issue of September 16 a letter in which he gave further examples of poems on scientific themes, among them being an "exquisite and delicate fantasy" which he attributed to the late Sir Arthur Shipley. Mr. H. S. Webster, 53 Loraine Road, London, N.W.7, has, however, written to Mr. Heron-Allen to point out that the verses were from a poem entitled "Solomon Redivivus, 1886" by Constance Naden, published in the volume of her complete poetical works, reviewed in NATURE of October 18, 1894. The poem consists of sixteen quatrains, three of which read as follows :-

We were a soft Amœba

In ages past and gone,

Ere you were Queen of Sheba,

And I King Solomon.

Unorganed, undivided,

We lived in happy sloth,

And all that you did I did,

One dinner nourished both :

Till you incurred the odium

Of fission and divorce-

A severed pseudopodium

You strayed your lonely course.

\section{National Radium Trust}

OwING to a rise of $30-40$ per cent in the price in sterling of radium, consequent on the departure of Great Britain from the gold standard, the National Radium Trust pursued a conservative policy during 1932-33 and purchased only $3.76 \mathrm{mgm}$. of new radium, the needs of radium treatment centres being met by a re-distribution of the stock held. The Radium Commission has published details of the general policy adopted with regard to radium therapy for cancer, and summaries of reports from radium treatment centres (Fourth Annual Reports of the National Radium Trust and Radium Commission, 1932-1933. H.M. Stationery Office).

\section{Health in the Tropics}

THE October supplement of the Tropical Diseases Bulletin summarises the medical and sanitary reports from British Colonies, Protectorates and Dependencies 